\title{
NUTRIENT RESERVE DIFFERENCE BETWEEN YOUNG AND ADULT SHORT- TAILED SHEARWATERS, PUFFINUS TENUIROSTRIS, BEFORE AND AFTER TRANS-EQUATORIAL MIGRATION
}

\author{
by Nariko Oka
}

(with five text-figures and one table)

\begin{abstract}
Oka, N. 2008 (31:x): Nutrient reserve difference berween young and adult Short-tailed Shearwaters, Puffinus tenuirostris, before and after trans-equatorial migration. Papers and Proceedings of the Royal Society of Tasmania 142(1): 197-204.

https://doi.org/10.26749/rstpp.142.1.197 ISSN 008-4703. Yamashina Institute for Ornithology, 115 Konoyama,

Abiko, Chiba, 270-1145 Japan. Email: oka@yamashina.or.jp

The Short-tailed Shearwater, Puffinus tenuirostris, is a trans-equatorial migrant, breeding in Tasmania and other parts of southeastern Australia during the Austral summer and migrating to the northern North Pacific for the Boreal summer. Juveniles, in particular, suffer considerable mortality during the migration. Body composition of juveniles and adults in terms of body mass, lipid content, pectoral muscle mass and bone marrow content, before and after migration was investigated. Juveniles varied greatly in body composition pre- and post-migration and took longer to recover their nutritional status than adults. Adults sustained a better body composition, showing a moderate decrease in body fat upon arrival in the nortb and recovering their body mass and lipid supply during their stay. The lipid content $\bullet$ f beachcast bird carcasses (mean, $4 \mathrm{~g}$ ) was the minimum necessary for cell membranes and was not metabolisable for energy. Pectoral muscle protein remained high among birds under hyper-nutritional conditions, and decreased gradually at first as lipids decreased, and then rapidly at late malnutritional stages when most lipids had been utilised for energy. Although adults sustained their nutritional status, the amount of lipids in adults leaving the Tasmanian colony was insufficient to accomplish the løng-distance migration, so post-breeding adults probably first visited Antarctic waters to accumulate fat reserves before commencing their northward migration.
\end{abstract}

Key Words: age group, body composition, fat deposit, marrow, nutritive difference, pectoral muscle, protein, Puffinus tenuirostris, Short-tailed Shearwater, trans-equatorial migrant.

\section{INTRODUCTION}

Long-distance migrations through areas with poor nutrient productivity are critical events for some animals. Recent evidence has shown that the Sooty Shearwater, Puffinus griseus (J.F. Gmelin, 1789), a New Zealand trans-equatorial migratory seabird, traversed low-latitude waters with low productivity at mean speeds as high as $910 \mathrm{~km}$ per day while rarely foraging (Shaffer et al. 2006). To accomplish these long journeys without refueling, they must have sufficient energy reserves, though the storage abilities of most birds are limited by the constraints of flight and wing loading.

The Short-tailed Shearwater, Puffinus tenuirostris (Temminck, 1835), which breeds in Tasmania and other parts of southeastern Australia during the Austral summer (October to April), migrates one of the longest distances of any migratory bird, annually completing a trans-equatorial migration to spend the Boreal summer (May to September) in the highly productive waters of the northern North Pacific, Okhotsk Sea and Bering Sea (Serventy et al. 1971, Shuntov 1974, Warham 1996). This species has evolved a feeding apparatus that allows it to take small marine animals effectively (Morgan \& Ritz 1982), which are sparsely distributed in tropical and sub-tropical oceans along its migratory pathway (Reid 1962). Thus, the survival of the migrants may depend greatly on energy deposits acquired before departure from the cool waters of the higher latitudes of both hemispheres.

The Nemuro Strait (about $44^{\circ} \mathrm{N}$ latitude), which separates eastern Hokkaido from the Kuril Islands, is the southernmost limit of the waters where the Short-tailed Shearwater spends the Austral winter. Along the Japanese coast, bathed by the warm Kuroshio Current $1300 \mathrm{~km}$ south of the strait, comprising the final stretch of the shearwaters' northward trans-equatorial migration, mortalities occur regularly during the two weeks from late May to early June (Oka et al. 1986).

Mass mortalities occurred at about 10-year intervals in the second half of the twentieth century: 1964, 1973-75, 1983-85 and 1996 (Kawaguchi \& Marumo 1964, Sugimori et al. 1976, Oka \& Maruyama 1986, Taguchi \& Kato 1997). Age estimates based on skull ossification of the 2250 beachcast bird carcasses collected along the central Japanese coast from the mass mortality events of the mid1980 s revealed that almost all of them $(99.5 \%)$ were fourmonth-old juveniles that had died from starvation (Oka \& Maruyama 1986).

In the current century mass mortalities continued occurring along the central Japanese coast in the same period of late May-early June in 2003, 2005 and 2006, suggesting that those casualties were also migrating juveniles.

During the Boreal summer, mass mortalities of Short-tailed Shearwaters occurred in the Bering Sea in 1997 (Baduini et al. $2001 \mathrm{a}, \mathrm{b}$ ) and in the Okhotsk Sea in 2007 (Hokkaido Government, unpublished data). These mortalities suggest that some birds postponed recovering from energy shortage. Unfortunately the age of the birds in both these mass mortality events was not determined, but evidence from previous events suggests that it is more likely that they were inexperienced fledglings rather than experienced sub-adult or adult birds. As shearwater fledglings migrate independently to the Northern Hemisphere and remain apart from older birds while there, they have little foraging experience or knowledge of local waters suitable for feeding; thus, their survival is most likely lower than that of older birds, with differing energy storage among age groups.

Knowledge of energy storage differences among the shearwater age classes before and after the northern migration and the time to recover from energy shortage is important not only to clarify the reasons for the recent mortality 
events observed in the Northern Hemisphere but also to understand the higher survivorship of adults (Bradley et al. 1989) from the viewpoint of nutritional ecology. I here report body composition differences in juvenile and adult Short-tailed Shearwaters and composition changes preand post-migration, focusing in particular on the disparity in nutritional recovery in the far northern waters of the Northern Hemisphere.

\section{MATERIALS AND METHODS}

\section{Study animals}

The Short-tailed Shearwater, Puffinus tenuirostris, is a longdistance migrant, which breeds in Tasmania and in other parts of southeastern Australia and overwinters in the North Pacific and Bering Sea and Okhotsk Sea (Marchant \& Higgins 1990). The breeding season of Short-tailed Shearwaters comprises the 195 days from October to April $(53 \%$ of each year; Warham 1990). The female lays a single egg in a burrow in late November (Marchant \& Higgins 1990 , Warham 1990). After the chick hatches in mid-January, the adults rear the nestling for about 85 days, until early April (Oka 1989). During this time, the chick increases its body mass until it weighs on average 1.4 times at maximum the weight of adults (Marchant \& Higgins 1990). Beginning in early April, after provisioning the nestlings with a final meal, the adults leave their breeding grounds for the transPacific migration, probably via Antarctic waters as a satellite tracking experiment suggests (Nicholls et al. 1998). During the subsequent two or three weeks, the body mass of the nestlings decreases, and they fledge in late April (Oka 1989), after their feathers have developed to adult condition (Lill \& Baldwin 1983, Oka 1989). Most juveniles depart their hatching sites shortly after fledging (Naarding 1980). Since the juveniles depart later than the adults, they also arrive later at their overwintering sites in the North Pacific than the adults (Marchant \& Higgins 1990). Large flocks of birds (presumably adults, judging from the departureschedule from the breeding grounds) first appear along northern Japanese coasts in the westernmost North Pacific in late April to early May (Niizuma \& Shibano 1983, Watabe et al. 1987), and they first appear in the Bering Sea around the end of April (Shuntov 1974). Large flocks of fledglings appeared in Japanese waters from around 20 May to early June (Oka 1986). Adults leave the northern North Pacific and Bering Sea for their Australian breeding sites in September. They are followed by sub-adults and young one or two months later. Short-tailed Shearwaters are long-living seabirds, with $87-95 \%$ annual survivorship (Bradley et al. 1989). They begin to breed at about 6-7 years of age (Bradley et al. 1989).

\section{Materials}

A total of 263 Short-tailed Shearwaters were used in this study: 31 birds (17 nestlings, 14 adults) were captured in burrows at the Clifton Bluff breeding colony in Tasmania, Australia ( $\left.42^{\circ} 55^{\prime} \mathrm{S}, 147^{\circ} 19^{\prime} \mathrm{E}\right)$ (fig. 1, location 1), in April 1983 , weighed using a spring balance with $10 \mathrm{~g}$ calibration, and immediately released after these measurements were taken. A further 232 birds were collected from 4 April 1983-30 May 1984, euthanased (if not already dead) and frozen for later laboratory analysis. Of these birds 59 (50 adults, nine nestlings) were caught from burrows at their breeding grounds

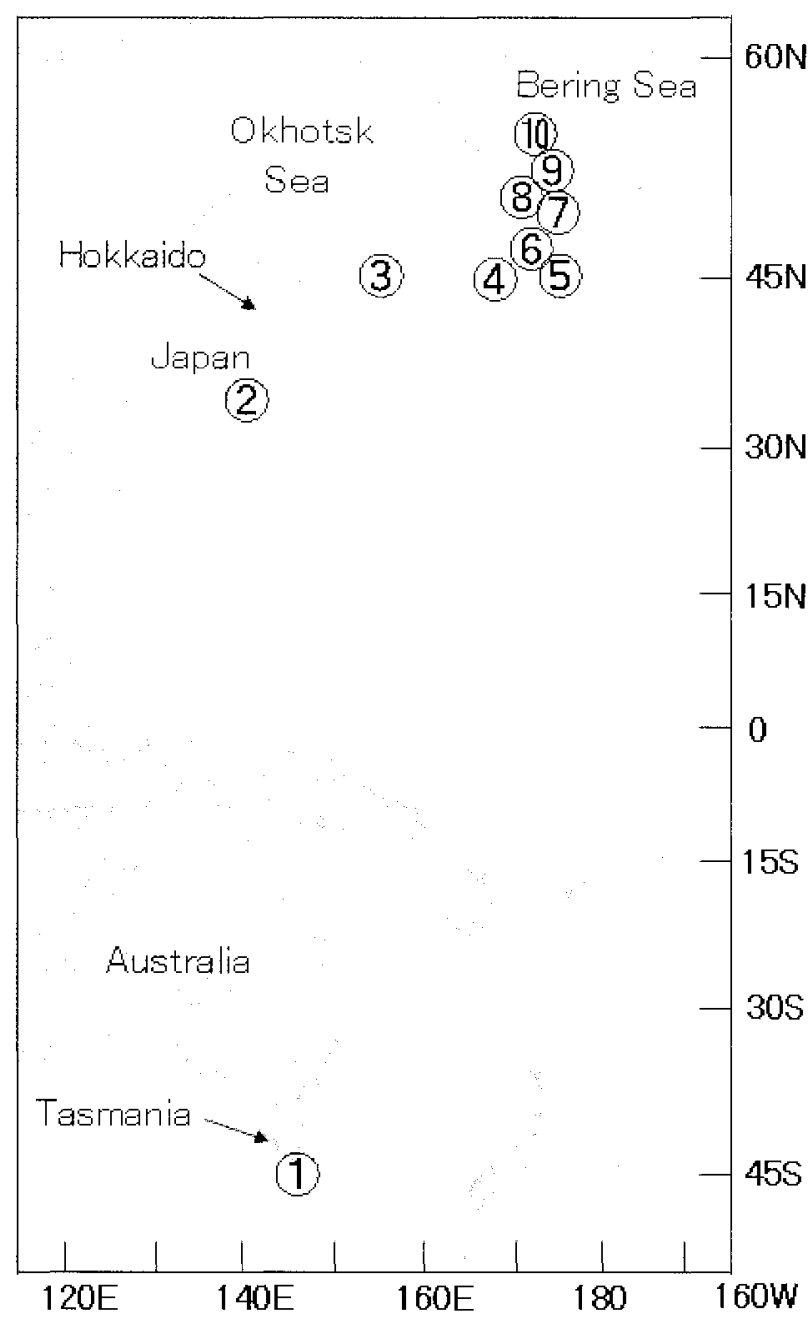

FIG. 1 - Short-tailed Shearwater sampling locations.

at the Clifton Bluff colony in Tasmania from 23 November 1983 to 20 April 1984; 60 fresh beachcast bird carcasses and 23 accidental bycatch birds from fishing nets were collected from Japan (collection points about $36^{\circ} \mathrm{N}$ in the North Pacific along the Japanese coast) (fig. 1, location 2), from 24 May to 7 June 1983 and on 30 May 1984, when the shearwaters are at the final stretch of their migration; and 90 bycatch birds were collected from drift nets in the northern North Pacific and Bering Sea (between $44.50-55^{\circ} 25^{\prime} \mathrm{N}$ ) from 5 May to 23 July 1983, where they spend the boreal summer (fig. 1, locations 3-10). Except for beachcast birds, all birds collected from the North Pacific waters and Bering Sea were bycatch, so they were alive at the time of capture.

\section{Age and phase groups}

Birds were classified into two age groups: young $(n=147$ with 26 nestlings and 121 juveniles) and adults ( $\mathrm{n}=116)$. Young birds were further classified into four phase groups: old nestlings ( $\mathrm{n}=26)$ (captured in burrows in Tasmania in fledging period); dead juveniles $(n=60)$ from Japanese coasts (beachcast birds from around $\left.36^{\circ} \mathrm{N}\right)$; juveniles $(\mathrm{n}=$ 23) collected in late May or early June upon their arrival (AR) at $45-48^{\circ} \mathrm{N}$ in the North Pacific, in the convergence zone of the warm Kuroshio Current with the sub-Arctic Oyashio Current; and juveniles ( $n=15$ ) collected from the 
sub-Arctic Current waters north of $48^{\circ} \mathrm{N}$ to $55^{\circ} \mathrm{N}$ in the North Pacific and Bering Sea in July, during their stay (ST) in the Northern Hemisphere.

Adults collected from the North Pacific and Bering Sea during the Boreal summer were divided into two phase groups: those collected upon arrival (AR) in early to midMay from the waters at $45-48^{\circ} \mathrm{N}$ in the North Pacific (n =37), and those collected from sub-Arctic current waters north of $48^{\circ} \mathrm{N}$ to $55^{\circ} \mathrm{N}$ in the North Pacific and Bering Sea in late June to July during their Northern Hemisphere stay $(S T)(n=15)$. The timing of the AR and ST periods differed between the age groups, because, conservatively estimated, adults in Australia start their northward migration two weeks before the juveniles.

The ages of the birds collected outside the burrows at the colony were determined via skull ossification (Sugimori et al. 1986), which distinguishes juvenile Short-tailed Shearwaters from older birds. This method cannot be used to divide older birds into adults and sub-adults, so the adults collected from waters of the North Pacific may have included sub-adults.

\section{Laboratory procedure}

The 232 birds used for the laboratory analysis were deepfrozen in zippered plastic bags soon after collection to prevent desiccation and were preserved in good condition until examination in 1984. Wet body and pectoral muscle masses and liver and stomach contents were weighed using a top-loading precision electronic balance $( \pm 0.01 \mathrm{~g})$. Wet pectoral muscle weights were doubled for the analysis (i.e., full breast).

The carcasses were plucked by hand before dissection to prepare them for body lipid extraction. The following parts were removed from the naked body: the head (for aging); the bones of the legs and wings (for marrow analyses); the stomach and its contents; the intestines; the liver; and one side of the pectoral muscle. The liver and the one side of the pectoral muscles were first weighed and then individually minced by scissors and homogenised well; about $7 \mathrm{~g}$ of each sample was then collected for determination of the dry weight/wet weight ratio and the lipid and protein contents. The body carcass was minced, by passing it through a meat grinder three times using two kinds of grid sizes of blade, with hand mixing between passes to homogenise the sample. After thorough homogenisation, $7 \mathrm{~g}$ of each wet minced sample was individually weighed in the extraction thimbles using a top-loading precision electronic balance $( \pm 0.001 \mathrm{~g})$ and dried in a convection oven at $50^{\circ} \mathrm{C}$ for 8 hours until a constant weight was reached. The femora were cracked, and the marrow was removed as completely as possible from the bone with forceps and weighed. The marrow was dried to constant weight in a convection oven at about $50{ }^{\circ} \mathrm{C}$ for 3 hours, and the dry weight $\%$ (ratio of the dry weight to the wet weight) was recorded. Because not all measures were available for all birds sampled, sample sizes in the laboratory analyses differed from the numbers of birds collected.

Lipids were extracted from each dried sample by a Soxhlet extractor for 12 hours using an alcohol-benzene (1:1) solution. The lipid content and the lipid-free contents dried to a constant weight were weighed. The body lipid content given in this study is the total of the lipids extracted from the minced body and those in the liver and pectoral muscle side previously removed.

\section{Statistical analysis}

Because no significant differences were found in any variable of the body composition of the 60 beachcast juvenile Shorttailed Shearwaters between 1983 and 1984 (table 1), I pooled the data for those two years. To test for significant differences in the beachcast juveniles between the two years, I used the Student $t$-test, as all variables were homoscedastic (body mass, $F_{10,48}=0.530, p=0.2102$; body lipids, $F_{4,16}=4.433, p=$ 0.0932 ; dry body weight $\%, F_{4,16}=5.76, p=0.5072$; wet pectoral muscle mass, $F_{10,48}=0.4353, p=0.5915$; protein content in pectoral muscles, $F_{5,23}=0.838, p=0.8070$; liver mass, $F_{10,33}=2.024, p=0.1810$; dry femur marrow weight $\%, F_{10,47}=1.018, p=0.9714$; dry tibia marrow weight $\%$, $F_{10,44}=0.633, p=0.3670$ ).

There were no significant differences in body mass in old nestlings $(n=26)$ in late April or in adults $(n=27)$ at the final landing period in late March and/or early April between 1983 and 1984 (between nestlings for two years: unpaired $t$-test, $t_{24}=0.365, p=0.7185$; between adults for two years: unpaired $t$-test, $t_{25}=0.658, p=0.5164$ ), using the Student $t$-test for significant differences, as variances

Table 1

Comparison of body composition of beachcast birds in Japan between 1983 and 1984

\begin{tabular}{|c|c|c|c|c|c|c|c|}
\hline & \multicolumn{3}{|c|}{1983} & \multicolumn{3}{|c|}{1984} & \multirow[b]{2}{*}{$p$} \\
\hline & $n$ & Mean & SD & $n$ & Mean & SD & \\
\hline Body mass (g) & 11 & 297.3 & 17.54 & 49 & 285 & 24.09 & ns \\
\hline Body lipids (g) & 5 & 4.79 & 2.881 & 17 & 4.29 & 1.368 & ns \\
\hline Body lipids (\%) & 5 & 1.63 & 0.905 & 17 & 1.45 & 0.367 & ns \\
\hline Dry body weight (\%) & 5 & 12.1 & 1.65 & 17 & 12 & 2.18 & ns \\
\hline Pectoral muscle mass $(\mathrm{g})$ & 11 & 26.6 & 4.13 & 49 & 27.5 & 5.03 & ns \\
\hline Dry pectoral muscle content (\%) & 11 & 22.7 & 1.99 & 47 & 22.5 & 1.73 & ns \\
\hline Dry tibia marrow content (\%) & 11 & 11.1 & 4.41 & 48 & 8.9 & 4.37 & ns \\
\hline Dry femur marrow content $\%$ & 11 & 19.8 & 4.77 & 45 & 12.6 & 5.99 & $\mathrm{~ns}$ \\
\hline Liver weight $(\mathrm{g})$ & 11 & 4.8 & 1.37 & 34 & 4.2 & 0.96 & $\mathrm{~ns}$ \\
\hline Pectoral muscle protein $(\mathrm{g})$ & 6 & 4.4 & 1.08 & 24 & 5 & 1.18 & $\mathrm{~ns}$ \\
\hline Pectoral muscles/body mass (\%) & 11 & 8.9 & 1.09 & 49 & 9.6 & 1.55 & ns \\
\hline
\end{tabular}


were homoscedastic, respectively. I, therefore, used the data set of those birds collected in 1984 to compare the body composition variables among the different phase groups collected in 1983.

Because the body mass and body composition variables of both adults and young among three phase groups, before migration (i.e., shortly before leaving the colony in Tasmania), after migration (AR), and during their stay in the northern North Pacific and Bering Sea (ST), were heteroscedastic (i.e., with statistically unequal variances), I used the non-parametric Kruskal-Wallis rank test to determine significant differences in body mass and in body composition among these phase groups for both age groups. This was followed by non-parametric Mann-Whitney $U$-tests to compare the heteroscedastic variables between the two age groups. Statistical analyses were performed with Statview 5.0. All measurements in the text are given as means \pm 1 standard deviation.

\section{RESULTS}

\section{Body mass before and after migration}

The mean body mass of young and adult Short-tailed Shearwater groups differed among the three phase groups, before migration (i.e., shortly before leaving the colony in Tasmania), after migration (AR) (i.e., shortly after arriving at the boreal summering waters), and during their stay in the northern North Pacific and Bering Sea (ST) (Kruskal-Wallis rank test, adults: $H=22.37, p<0.0001, n=66$; juveniles: $H$ $=36.15, p<0.0001, n=55$ ) (fig. 2). The lowest mean body masses were found in both age groups upon arrival in the North Pacific (AR group). The body mass of adults was low $(517 \pm 31.4 \mathrm{~g}, n=37)$ and that of juveniles was the lightest (397 $\pm 41.0 \mathrm{~g}, n=26)$ among all age and phase groups. During their stay in the northern North Pacific and Bering Sea in July (ST group), adults recovered their mean body mass to $583 \pm$ $68.3 \mathrm{~g}(n=15)$, a value significantly similar to that of adults at the final landfall in early April (AR group; Mann-Whitney $U$-test, $U=91, z=-0.611, p=0.5407)$, whereas juveniles in the ST group showed only a moderate increase in body

(A)

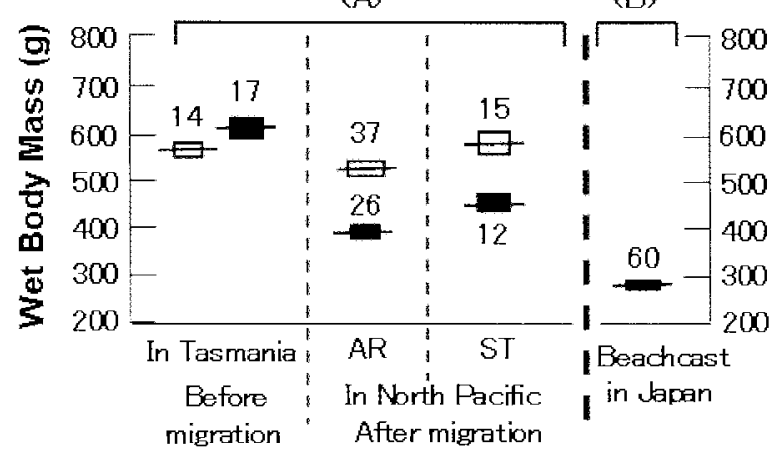

FIG. 2 - Comparison of the body masses of young (black symbols) and adult (open symbols) Short-tailed Shearwaters before and after migration $(A)$ and of beachcast birds that died during migration (B). AR indicates data collected at the time of the birds' arrival at the North Pacific for the Boreal summer, and ST indicates data collected later during their stay in the North Pacific. The mean (horizontal line) and standard error are shown. mass to $449 \pm 61.5 \mathrm{~g}(n=12)$ (Mann-Whitney $U$-test, $U$ $=75, z=-2.544, p=0.011$ ), compared with the AR group, a value about $130 \mathrm{~g}$ lighter than the mass of adults spending the boreal summer in the northern North Pacific or Bering Sea and $160 \mathrm{~g}$ lighter than the mean value for old nestlings in fledgling period in Tasmania in late April.

\section{Relationship between body mass and body lipid content by weight}

Body mass and the amount body lipids (g) were highly correlated $\left(r^{2}=0.79, p<0.001, n=153\right)$ in the pooled data set of Short-tailed Shearwater age and phase groups ranging from $220-701 \mathrm{~g}$ in body mass, and from 2.6-149.3 g in body lipids, excluding nestlings. That was because the nestlings were in hyper-nutritive condition, characterised by a large amount of body lipids $(262.3 \pm 38.5 \mathrm{~g}, n=9)$ accounting for $42.0 \%$ of their average body mass $(622 \pm 68.4 \mathrm{~g}, n=9)$. The equation of the exponential correlation function is:

$$
y=10.932-0.151 x+(4.564)^{-4} x^{2}
$$

where $y$ is body lipids and $x$ is body mass. Body lipids reached a minimum of a few grams when the body mass had decreased to around $300 \mathrm{~g}$ or less (fig. 3).

\section{Relationship between body lipids and muscle protein}

Body lipids and protein in the pectoral muscles were also highly correlated in the Short-tailed Shearwaters $(y=4.65$ $+0.285 x-0.002 x^{2} ; r^{2}=0.76, p<0.001, n=76$ ) where $y$ is protein in pectoral muscles $(\mathrm{g})$ and $x$ is body lipids $(\mathrm{g})$ (fig. 4).

Protein content was approximately constant at a high level in birds storing large amounts of fat, but decreased gradually as body lipids decreased below about $60 \mathrm{~g}$. In birds that had lost most of their body lipids, the protein content had decreased to just a few grams (fig. 4).

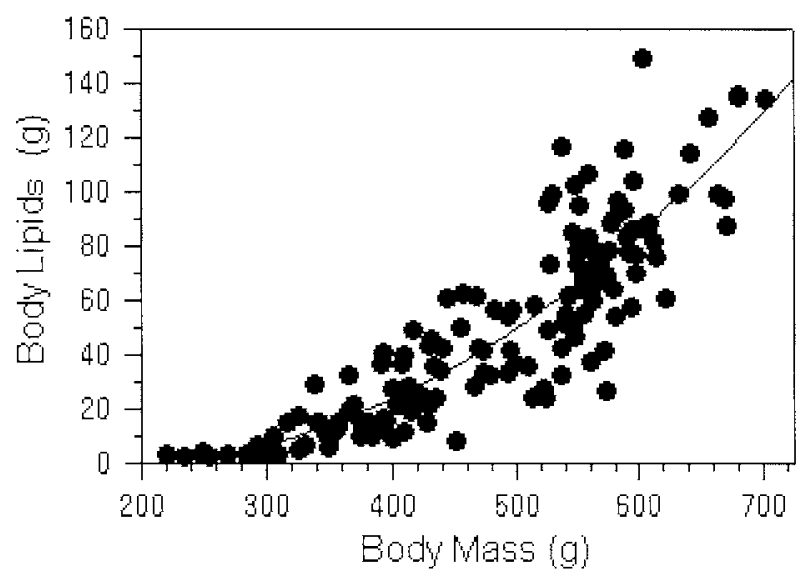

FIG. 3 - Relationship between body mass and body lipid content in Short-tailed Shearwaters. 


\section{Beachcast birds}

The mean body mass of beachcast young Short-tailed Shearwaters dying during migration was significantly lower than that of AR group (Mann-Whitney $U$ test, $U=8.5$, $z=7.255, p<0.0001$ ) (fig. 2B). The beachcast birds retained only a mean lipid content of $4.4 \pm 1.74 \mathrm{~g}$ (range, $2.62-9.84$ g, $n=22$ ) (fig. 5 ), accounting for a mean $1.5 \pm 0.51 \%$ (range, $1.1-3.2 \%, n=22$ ) of the very lean average body mass of 287 g. They also had a small pectoral mass (fig. 5B); the pectoral muscle weighed $27.3 \pm 4.86 \mathrm{~g}$ (range, $17.2-41.1 \mathrm{~g}, n=60$ ), with only $4.9 \pm 1.17 \mathrm{~g}$ of protein (range, $3.4-8.2 \mathrm{~g}, n=30$ ). Liver mass was $4.6 \pm 1.25 \mathrm{~g}$ (range, $3.0-8.3 \mathrm{~g}, n=45$ ) (fig. $5 \mathrm{~B}$ ). The marrow content of the dried femur and tibia was only $14.0 \pm 6.43 \%$ (range, $5.0-32.7 \%, n=56$ ) (fig. $5 \mathrm{~B}$ ) and

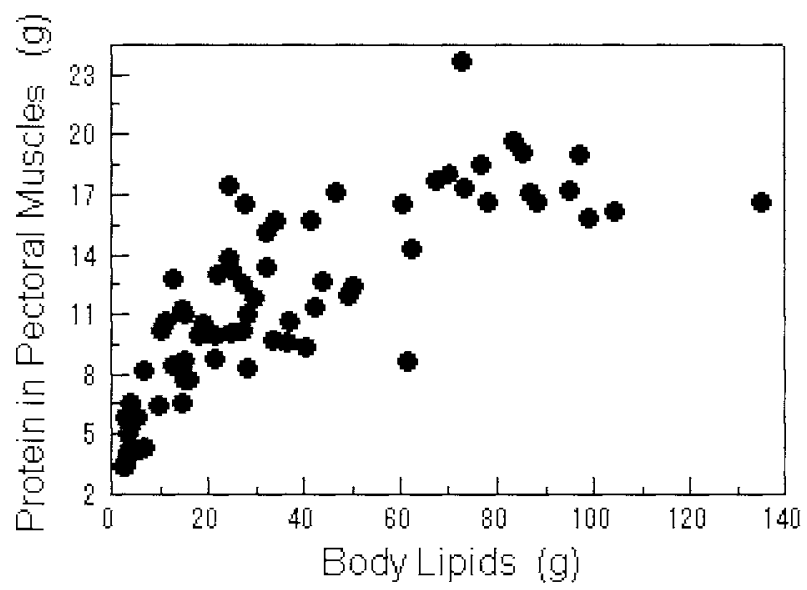

FIG. 4 - Relationship between the protein content in pectoral muscles and the body lipid content in Short-tailed Shearwaters.
$9.8 \pm 4.85 \%$ (range, $1.9-26.4 \%, n=59$ ), respectively. These low martow values indicated that the birds were alive until the suspension of their hematopoietic stem cell activities.

All of the lines of evidence showed that the beachcast young Short-tailed Shearwaters had exhausted theit nutrients to critical levels by the time they had reached the Japanese coast, which is the final and westernmost stretch of their migration pathway to the northern North Pacific.

\section{BODY COMPOSITION}

\section{Post-migratory birds}

Post-migratory AR young stored $26.2 \mathrm{~g}( \pm 15.22 \mathrm{~g}, n=23)$ of body lipids (fig. 5), which accounted for $6.6 \%$ of the lean average body mass of $397 \mathrm{~g}$, whereas post-migratory AR adults stored $41.0 \mathrm{~g}( \pm 13.03 \mathrm{~g}, n=13)$ of body lipids, accounting for $7.9 \%$ of the average $517 \mathrm{~g}$ of body mass. The amount of fat stored by the post-migratory young was therefore only $10 \%$ of that of the obese nestlings sampled during the fledging period at the colony in Tasmania (mean body lipids, $262.3 \mathrm{~g}$, $42 \%$ of the $622 \mathrm{~g}$ body mass; 20 April 1984) (fig. 5). Moreover, upon their arrival in the northern North Pacific (AR group), juveniles had similar fat levels to juveniles that were collected later, i.e., during their stay in the North Pacific and Bering Sea (unpaired $t$-test, $t_{30}=0.066, p$ $=0.948$ ). On the other hand, post-migratory adults stored $71.4 \mathrm{~g}( \pm 30.94 \mathrm{~g}, n=15)$ lipid, that was similar to the body lipids stored by pre-migratory adults leaving the colony in Tasmania in $1984(84.4 \pm 16.15 \mathrm{~g}, n=13)$ (Mann-Whitney $U$ test, $U=71, z=-1.221, p=0.222)$. Though the pectoral muscle mass decreased significantly even in the adults from before to after migration (unpaired $t$-test, $t_{48}=2.703, p=$ 0.01 ), the decrease was moderate (<10\%) (fig. 5 ).
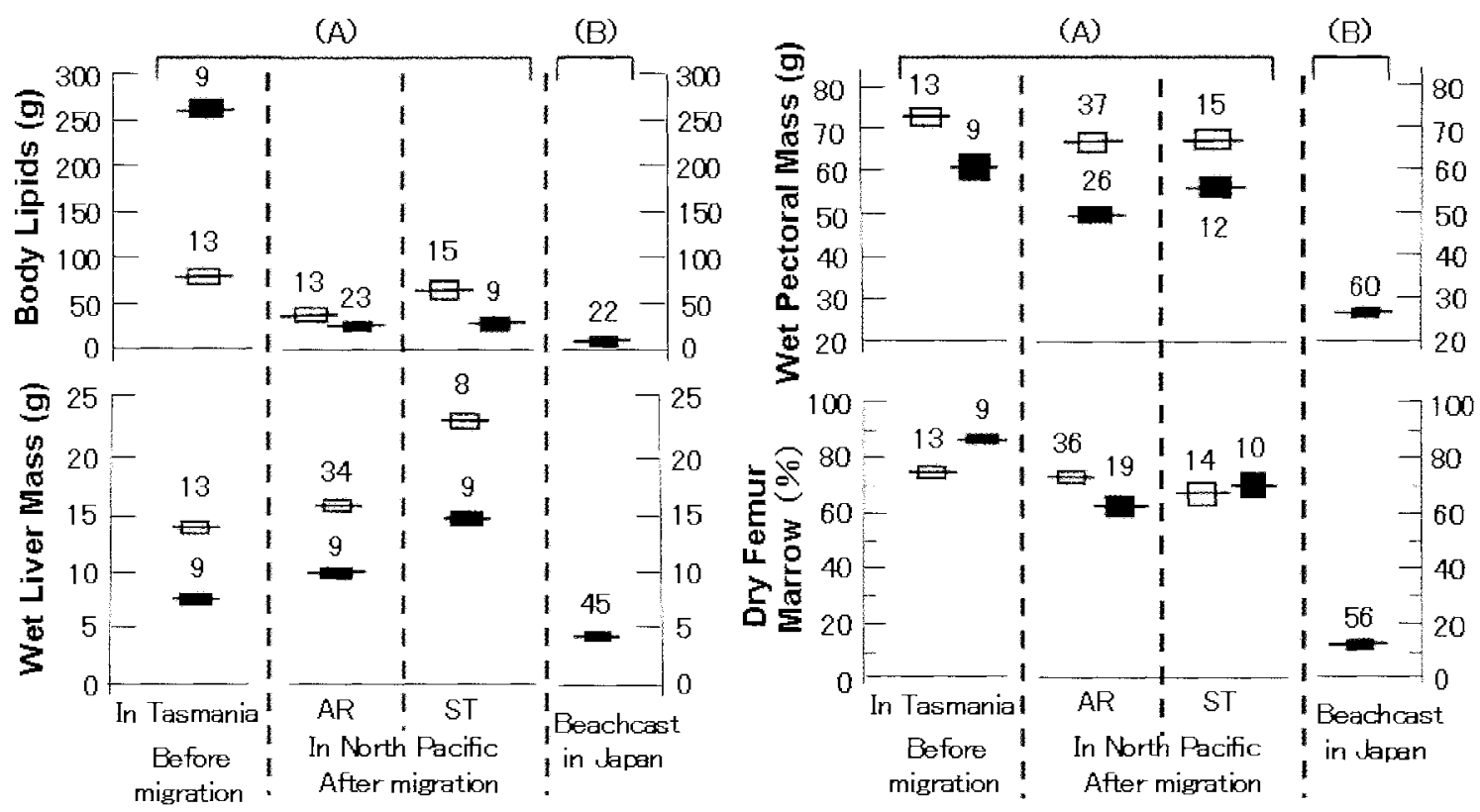

FIG. 5 - Comparison of the body masses of young (black symbols) and adult (open symbols) Short-tailed Shearwaters before and after migration $(A)$ and of beachcast birds that died during migration (B). AR indicates data collected at the time of the birds' arrival at the North Pacific for the boreal summer, and ST indicates data collected during their stay in the North Pacific. The mean (horizontal line) and standard error are shown. 
The fat levels after migration (AR groups) were larger in both young $(26.2 \pm 15.21 \mathrm{~g}, n=23)$ and adults $(41.0 \pm$ $13.03 \mathrm{~g}, \mathrm{n}=13$ ) than the mean minimum value found in the dead birds (beachcast birds: $4.4 \mathrm{~g}, \mathrm{n}=22$ ). Their residual lipid capacities therefore were sufficient for use not only for energy for basal metabolism but also for foraging in local waters. Although the AR young had lost their nutritive reserves to some degree during migration, they sustained high contents of dry femur marrow (AR group, $62 \pm 21.5 \%, n$ $=19$; ST group, $70 \pm 17.5 \%, n=10$ ) (fig. 5) that did not differ significantly from the adult AR (mean, $72.9 \pm 6.23 \%$, $n=13$ ) and ST (mean, $68.0 \pm 19.16 \%, n=14$ ) groups (Kruskal-Wallis rank test, $K_{5}=3.684, p=0.595$ ).

Adults in the northern North Pacific in late June to July (ST group) had the largest wet liver mass $(23.0 \pm 2.55 \mathrm{~g}$, $n=8$ ) among all phase and age groups (fig. 5), indicating a high intake efficiency while foraging.

\section{DISCUSSION}

Body lipids in Short-tailed Shearwaters are both a structural component necessary for cell membranes, and thus not available as a metabolic energy source, and a stored body fat component, including a distinctive oil stored in the upper layer of the stomach, which can be mobilised as a metabolic energy source.

The data presented here on lipid content from beachcast juvenile birds and from adults at the breeding colony led to a number of important observations.

The juvenile Short-tailed Shearwaters beachcast along Japanese shores during the northern migration had a remaining mean body lipid content of $4 \mathrm{~g}$, which is comparable to the mean value of $3 \mathrm{~g}$ in starved birds of unknown age in the Bering Sea, reported by Baduini et al. (2001b). Oka \& Okuyama (2000) reported that beachcast Rhinoceros Auklets, Cerorbinca monocerata (Pallas, 1811), found after an oil spill, had a mean body lipid content of $7 \mathrm{~g}$ and dry femur marrow content of $24 \%$. These auklets, which are short-distance migrants and a slightly heavier species than the shearwaters, had also lost most of their nutritional energy reserves and had suspended hematopoietic stem cell activity.

The body lipids remaining in the beachcast Short-tailed Shearwaters, therefore, should not be regarded as available for metabolic energy needs but as structural components of cell membranes (Klasing 1998). Thus, this species of bird requires extra lipids for energy, in addition to the $4 \mathrm{~g}$ needed for structural components. The beachcast juveniles also had only a small amount of protein in their muscles, as has been found in starved penguins (Cherel et al. 1994). The present study also shows that protein had a tendency to be consumed at the malnutritional stage after body lipid was mostly consumed.

The two mean body mass values (564 $\mathrm{g}$ with empty stomachs, and $569 \mathrm{~g}$, possibly including stomach contents) for the adult birds collected in this study at the colony in southern Tasmania during the departure period compares well with adult values measured by other studies at colonies during the late chick-rearing season (e.g., $574 \mathrm{~g}$ mean body mass with empty stomachs; northernmost Montague Is. population, New South Wales, Schultz \& Klomp 2000; and 583 g mean body mass, possibly including stomach content; Cape Woolamai population on Phillip Island, Victoria, Lill \& Baldwin 1983). The data can thus be interpreted as indicating the standard nutritive condition of adults.

As body mass and body fat have been previously shown to be positively correlated in Rhinoceros Auklets (Oka \& Okuyama 2000) and Short-tailed Shearwaters (Baduini et al. $2001 \mathrm{~b}$ ), consistent with the results of the present study, the moderate body mass of $564 \mathrm{~g}$ with a mean body fat content of $83 \mathrm{~g}$ can be considered optimal from the viewpoint of keeping wing loading at a minimum to increase flight efficiency. This stable nutritive condition among adults is maintained by commuting from the breeding sites far south to abundantly productive Antarctic waters, where Antarctic Krill, Euphausia superba (Dana, 1852), is captured to replenish their energy reserves during the chick-rearing season (Weimerskirch \& Cherel 1998, Klomp \& Schultz 2000, Cherel et al. 2005). Even if the birds minimise energy expenditure during flight by dynamic soaring, their fat deposits are too small to accomplish the 9000 $\mathrm{km}$ long-distance migration from $42^{\circ} \mathrm{S}$ to $45^{\circ} \mathrm{N}$ through the low-productivity low-latitude waters. During the final long-distance foraging trip to Antarctic waters south of Tasmania prior to the equatorial migration, adults may replenish their fat deposit and distinctive stomach oil to some extent. During the trans-equatorial migration over low-productivity tropical waters, the birds would metabolise not only their stored fat but also some of the stomach oil for their energy requirements. Birds probably complete their trans-equatorial migration in minimal time to avoid wasting their limited amount of energy on opportunistic foraging efforts in areas of low productivity.

Body lipids reached a minimum of a few grams when the body mass had decreased to around $300 \mathrm{~g}$ or less. This suggests that the decrease in body mass during the final stages of malnutrition may reflect decreases in components other than body fat. Unlike lipid, protein generally is not viewed as an energy storage, but is considered to be used only after lipid reserves are exhausted (Blem 1990). Protein content in the pectoral muscles in the shearwaters was accelerated to decrease during the final critical stage of malnutrition. Though the pectoral muscle mass decreased significantly even in adults from before to after migration, the decrease was moderate, compared with the decrease in body lipid, that showed Short-tailed Shearwaters depend largely on body lipids to accomplish their long-distance migration.

Post-migratory juveniles sustained a low body mass with a small amount of body lipids. The results of this study indicate that juveniles take longer to recover from energy shortages than adults, possibly because they lack skill and experience in feeding on prey organisms.

During anomalous weather and oceanic conditions in the Bering Sea in 1997 and 1998, the shearwaters failed to accumulate sufficient energy, storing only a mean of $31 \mathrm{~g}$ and $45 \mathrm{~g}$ body fat by each North Pacific autumn, respectively. They also had lighter pectoral masses (Baduini et al. 2001a) at the time when the shearwaters usually commence their southward migration to Australia. In the North Pacific autumn of 1997, up to 200000 individuals were estimated to have starved to death (Baduini et al. $2001 \mathrm{~b}$ ). Interestingly, these fatalities had body and pectoral masses $25 \%$ larger than those of the beachcast juveniles along the Japanese coast in this study (380 g vs. $287 \mathrm{~g}$ for body mass, and $36 \mathrm{~g}$ vs. 27 $\mathrm{g}$ for pectoral mass, respectively). The ages of the dead birds in the 1997 mass mortality were not determined.

Comparison of the body and pectoral masses of these fatalities with those of the adult birds in this study suggests that many older age classes were involved in these events, as 
the structural weights of bone and organs such as muscles increase and develop with age. These mass mortalities in the Bering Sea differ ecologically from the mass mortalities in temperate waters in which migratory juveniles are repeatedly involved. The ages of the dead birds should be determined to understand the effects of these mass mortalities on the population ecology of Short-tailed Shearwaters, and longterm monitoring is essential to understand the nature of these events.

\section{ACKNOWLEDGEMENTS}

This study would have not been possible without the support of the late Dr Irynej Skira, who offered me birds for analysis from Tasmania, and Dr Haruo Ogi, who offered me birds for analysis from the northern North Pacific. I am indebted to Dr Naoki Maruyama and Dr Nagahisa Kuroda for their advice and encouragement throughout the study, and to Ms Akiko Suzuki, Ms Yasuko Arima and Ms Reiko Higashi for their support in the laboratory. I thank Dr Ursula Munro and an anonymous reviewer for valuable comments on an earlier draft of the MS. This research was partly supported by a grant from the Toyota Foundation. I dedicate this paper to the memory of Dr Irynej Skira (1950-2005), who made a substantial contribution to our knowledge of Short-tailed Shearwaters.

\section{REFERENCES}

Baduini, C.L., Hyrenbach, K.D., Coyle, K.O., Pinchuk, A., Mendenhall, V. \& Hunt Jr, G.L. 2001a: Mass mortality of Short-tailed Shearwaters in the south-eastern Bering Sea during summer 1997. Fisheries Oceanography 10(1): $117-130$.

Baduini, C.L., Lovvorn, J.R. \& Hunt Jr., G.L. 2001b: Determining the body condition of Short-tailed Shearwaters: implications for migratory flight ranges and starvation events. Marine Ecology Progress Series 222: 265-277.

Blem, C.R. 1990: Avian energy storage. Current Ornithology 7: 59-113.

Bradley, J.S., Skira, I.J., Wooller, R.D. \& Serventy, D.L. 1989: Age-dependant survival of breeding short-tailed shearwaters Puffinus tenuirostris. Joumal of Animal Ecology 58: $175-188$.

Cherel, Y., Gilles, J., Handrich, Y. \& Maho, Y.L. 1994: Nutrient reserve dynamics and energetics during long-term fasting in the king penguin (Aptenodytes patagonicus). Journal of Zoology in London 234: 1-12.

Cherel, Y., Hobson, K. A. \& Weimerskirch, H. 2005: Using stable isotopes to study resource acquisition and allocation in procellariiform seabirds. Oecologia 145: 533-540.

Kawaguchi, K. \& Marumo, R. 1964: Mass mortality of Slenderbilled Shearwater, Puffinus tenuirostris, in Suruga Bay. Miscellaneous Report of Yamashina Institute for Ornithology 14: 106-113.

Klasing, K.C. 1998: Comparative Avian Nutrition. Cab International, Wallingford, UK: $350 \mathrm{pp}$.

Klomp, N.I. \& Schultz, M.A. 2000: Short-tailed Shearwaters breeding in Australia forage in Antarctic waters. Marine Ecology Progress Series 194: 307-310.

Lill, A. \& Baldwin, J. 1983: Weight changes and the mode of depot fat accumulation in migratory Short-tailed Shearwaters. Australian Journal of Zoology 31: 891-902.

Marchant, S. \& Higgins, P.J. (eds) 1990: Puffinus tenuirostris Short-tailed Shearwaters. In Handbook of Australian,
New Zealand ir Antartic Birds, Vol. 1, Part A. Oxford University Press, Oxford: 632-644.

Morgan, W.L. \& Ritz, D.A. 1982: Comparison of the feeding apparatus in the muttonbird, Puffinus tenuirostris (Temminck) and the fairy prion, Pachyptila turtur (Kuhl) in relation to the capture of the krill, Nyctiphanes australis Sars. Journal of Experimental Marine Biology Ecology 59: $61-75$.

Naarding, J.A. 1980: Study of the Short-tailed Shearwaters Puffinus temuirostris in Tasmania. Special Report, Tasmanian National Parks and Wildlife Service and Australian National Parks and Wildlife Services, Hobart and Canberra: $80 \mathrm{pp}$.

Nicholls, D.G., Stampton, P., Klomp, N.I. \& Schultz, M.A. 1998 Post-breeding flight to Antarctic waters by a Short-tailed Shearwater Puffinus tenuirostris. Emu 98: 79-82.

Niizuma, Y. \& Shibano, N. 1983: An estimation of individual number of shearwaters forming a northward-migrating stream along the Pacific cost of east Hokkaido. Bulletin of Applied Ornithology 3: 41-43.

Oka, N. 1986: Observation on the emaciated and dead Short-tailed Shearwaters Puffinus tenuirostris, in the north-western sea area of the North Pacific in 1983. Journal of Yamashina Institute for Ornithology 21: 193-207.

Oka, N. 1989: Chick growth and development of the Short-tailed Shearwaters Puffinus tenuirostris in Tasmania. Journal of Yamashina Institute for Ornithology 21: 193-207.

Oka, N. \& Maruyama, N. 1986: Mass mortality of Short-tailed Shearwaters along the Japanese coast. Tori 34: 97-104.

Oka, N. \& Okuyama, M. 2000: Nutritional status of dead oiled Rhinoceros Auklets (Cerorhinca monocerata) in the Southern Japan Sea. Marine Pollution Bulletin 40: 340-347.

Oka, N., Sugimori, F. \& Iwase, Y. 1986: Mortality counts of Short-tailed Shearwaters at Shiinauchihama of Kujukuribeach, 1976-1982. Journal of Yamashina Institute for Ornithology 17: 23-27.

Reid Jr., J.L 1962: On the circulation, phosphate-phosphorus content and zooplankton volumes in the upper part of the Pacific Ocean. Limnology and Oceanography 7(3): 287-306.

Schultz, M.A. \& Klomp, N.I. 2000: Does the foraging strategy of adult Short-tailed Shearwaters cause obesity in their chicks? Journal of Avian Biology 31: 287-294.

Serventy, D.L., Serventy, V. \& Warham, J. 1971: The Handbook of Australian Seabirds. Read, Sydney: 254 pp.

Shaffer, S.A., Tremblay, Y., Weimerskirch, H., Scott, D., Thompson, D.R., Sagar, P.M., Moller, H., Taylor, G.A., Foley, D.G., Block, B.A. \& Costa, D.P. 2006: Migratory shearwaters integrate oceanic resources across the Pacific Ocean in an endless summer. Proceedings of the National Academy of Sciences USA 103(34): 12799-12802.

Shuntov, V. P. 1974: Sea birds and the biological structure of the ocean. Translated from Russian to English by Agence Tunisienne de Public Relations, Tunis: $565 \mathrm{pp}$.

Sugimori, F., Oka, N. \& Iwase, Y. 1976: A questionnaire survey of shearwater mortality, especially of Puffinus tenuirostris. Journal of Yamashina Institute for Ornithology 8: $113-131$.

Sugimori, F., Oka, N. \& Iwase, Y. 1986: Degree of skull ossification as a mean of aging Short-tailed Shearwaters. Journal of Yamashina Institute for Ornithology 17: 159-165.

Taguchi, K. \& Kato, C. 1997: Note on the mass mortality of Short-tailed Shearwaters found in coast of Kanagawa Prefecture in 1996. Bulletin of Kanagawa Prefecture Museum 18: $31-37$.

Warham, J. 1990: The Petrels: Their Ecology and Breeding Systems. Academic Press, London: $452 \mathrm{pp}$.

Warham, J. 1996: The Behaviour, Population Biology and Physiology of the Petrels. Academic Press, London: $613 \mathrm{pp}$.

Watabe, Y., Oka, N. \& Maruyama, N. 1987: Seasonal appearances 
of Short-tailed (Puffinus tenuirostris) and Sooty (Puffinus griseus) Shearwaters on the Tokyo-Kushiro line, Japan. Journal of Yamashina Institute for Ornithology 19: 117-124.

Weimerskirch, H. \& Cherel, Y. 1998: Feeding ecology of shorttailed shearwaters: Breeding in Tasmania and foraging in the Antarctic? Marine Ecology Progress Series 167:

261-274.

(accepted 7 October 2008) 